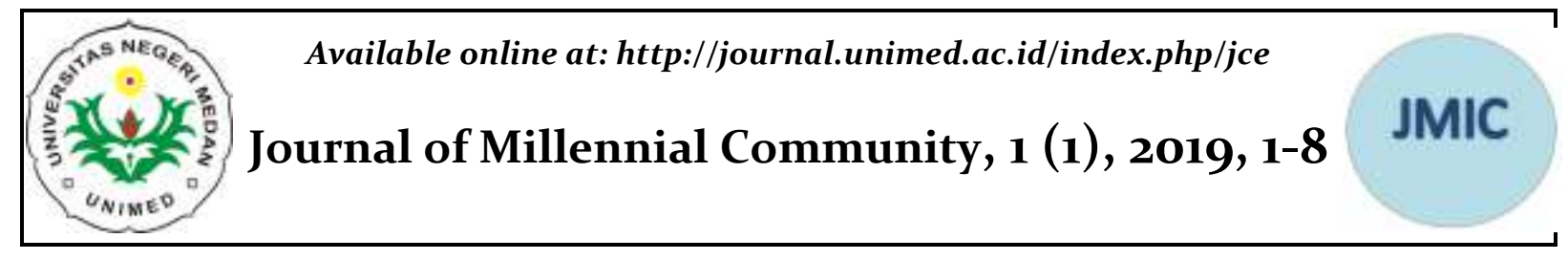

\title{
Faktor-Faktor Penyebab Rendahnya Minat Belajar Warga Belajar Paket C Di Kelompok Belajar Kemuning Desa Asahan Mati Kecamatan Tanjungbalai Kabupaten Asahan
}

\author{
Suriani ${ }^{1}$, Yusnadi ${ }^{2 *}$ \\ ${ }^{1}$ Bimbingan Belajar Kemuning, Kabupaten Asahan \\ ${ }^{2}$ Program Studi Pendidikan Masyarakat, Universitas Negeri Medan \\ *Korespondensi Penulis. Email: yusnadi@gmail.com
}

\begin{abstract}
Abstrak
Penelitian bertujuan untuk mengetahui faktor-faktor penyebab rendahnya minat belajar Paket C di Kelmpok Belajar Kemuning Desa Asahan Mati Kecamatan Tanjungbalai Kabupaten Asahan. Jenis penelitian ini menggunakan metode deskriptif kuantitatif. Populasi sebanyak 20 orang warga belajar. Sampel penelitian berjumlah 20 orang diambil dari semua populasi, dan teknik pengambilan sampel menggunakan sampling jenuh. Teknik pengumpulan data penelitian menggunakan angket. Teknik analisis data menggunakan rumus persentase $\mathrm{P}=\frac{F}{N} \times 100 \%$. Hasil penelitian menunjukkan bahwa minat belajar tidak pernah tumbuh dari dalam diri sendiri, hal ini sikap tersebut terlihat dari jawaban warga belajar lebih dominan memilih Setuju (S) sekitar 46\%. Motivasi belajar warga belajar juga tidak pernah timbul dari dalam diri warga belajar, hal ini terlihat ada sekitar 33,5\% warga belajar memilih Kurang Setuju (KS) lebih tinggi dari jawaban yang lain. Pengaruh membantu orang tua juga idak pernah mendorong minat belajar warga belajar, hal ini lebih dominan warga melajar memilih jawaban Kurang Setuju(KS) ada sekitar 46,5\%. Pengaruh bermain game online juga tidak mendorong minat belajar. Kesimpulan peneilitan menunjukkan bahwa warga belajar belum ada tumbuh minat belajar dari dalam diri sendiri, maupun dari luar diri warga belajar baik itu pengaruh dari keluarga, teman, dan lingkungan.
\end{abstract}

Kata Kunci: Minat Belajar, Kelompok Belajar, Kesetaraan Paket C

\begin{abstract}
The study aimed to determine the factors that caused the low interest in Equality program in learning the Kemuning Learning Group of Asahan Mati Village, Tanjungbalai District, Asahan Regency. This type of research uses descriptive quantitative methods. The population of 20 study residents. The research sample consisted of 20 people drawn from all populations, and the sampling technique used saturated sampling. The research data collection technique uses a questionnaire. The data analysis technique used the percentage formula $P=F / N$ $x 100 \%$. The results of the study showed that interest in learning never grew from within itself, this attitude was seen from the answers of the more dominant learning citizens choosing Agree (S) of about 46\%. Motivation to learn the learning population also never arises from within the learning community, this shows that there are around $33.5 \%$ of the people learning to choose Less Agree (KS) higher than the other answers. The influence of helping parents has also not encouraged the learning interest of the learning community, this is more dominant for the community to learn to choose Less Agree (KS) answers, there are around $46.5 \%$. The research conclusions show that there are no growing learning citizens who have an interest in learning from within themselves, as well as from outside the learning community both the influence of family, friends, and the environment.
\end{abstract}

Keywords: Learning Interest, Study Group, Equality Program 


\section{PENDAHULUAN}

Dalam rangka peningkatan sumber daya manusia Indonesia, pemerintah melaksanakan berbagai upaya, yang salah satu dari upaya tersebut adalah melalui pembagunan pendidikan, karena pendidikan merupakan kebutuhan dasar manusia dan merupakan langkah yang paling strategi untuk meningkatkan kualitas sumber daya manusia. Menyadari akan pentingnya Sumber Daya Manusia (SDM) yang berkualitas bagi satu negara, maka pemerintah dalam hal ini Direktorat Pendidikan Masyarakat, Direktorat Pendidikan Luas Sekolah, pendidikan nonformal adalah pendidikan yang diselenggarakan di luar sekolah melalui kegiatan belajar mengajar yang tidak berjenjang dan tidak berkesinambungan. Selain itu, dalam pendidikan non formal tidak ada keseragaman pola yang bersifat nasioanal dan modelnya sangat beragam. Depertemen Pendidikan Nasional, menyelenggarakan berbagai program yang salah satu diantaranya adalah pendidikan kesetaraan yang terdiri atas : (1.) Program paket $A$, yaitu program yang memberian pelayanan pendidikan setara Sekolah Dasar (SD) (2.) Program paket B, yaitu program yang memberikan pelayanan pendidikan setara menegah pertama (SMP) dan (3.) Paket $C$ yaitu program yang memberikan pelayanan pendidikan Setara Menengah Atas (SMA)/ (Heri, 2007).

Program Paket $\mathrm{C}$ adalah salah satu program pendidikan non- formal yang diselenggarakan oleh kelompok belajar kemuning dimana kelompok tersebut di bawah naungan Sanggar Kegiatan Belajar (SKB) Kabupaten Asahan Program ini di tujukan bagi masyarakat untuk yang melanjutkan sekolah pada tingkat setara SMA. Dengan telah menyelesaikan program pendidikan setara SMA maka diharapkan masyarakat tersebut mampu meningkatkan taraf hidupnya dan bersaing dengan mereka yang berasal dari status sosial ekonomi dan jenjang pendidikan yang berbeda. Bersaing dengan mengarahkan seluruh kemampuan yang diperoleh dari prestasi belajar yang telah dijalaninya.

Program paket $C$ yang telah di selenggarakan oleh SKB Kabupaten Asahan kelompok belajar kesetaraan paket $\mathrm{C}$ Page $\mid 2$ kelompok belajar Kemuning berada di desa Asahan Mati kec. Tanjungbalai kabupaten Asahan. Jarak antara kelompok dengan SKB tersebut sangat berjauhan, tetapi masih di bawah naungan SKB Asahan. Kelompok belajar Kemuning terdiri atas (20) orang warga belajar, tutor yang mengajar terdiri atas enam (6) orang. Proses pembelajaran dilakukan tiga kali dalam seminggu pada hari senin, selasa dan kamis dilakukan pada jam 2 sampai jam 4 sore.

Melalui proses belajar mengajar interaksi antara warga belajar Paket C kelompok belajar Kemuning dengan tutor terjalin. Dalam proses belajar mengajar tersebut terjadi proses tidak tahu menjadi tahu atau yang disebut dengan belajar. Secara umum belajar dapat diartikan sebagai suatu perubahan tingkah laku yang relatif menetap yang terjadi sebagai hasil dari pengalaman atau latihan. Yang dimaksud pengalaman adalah sengaja dilakukan oleh setiap orang, sedangkan latihan merupakan kejadian yang dengan sengaja dilakukan oleh setiap orang secara berulang-ulang.

Apabila di dalam proses belajar mengajar di kelompok belajar Kemuning Paket C tidak ada partisipasi warga belajarnya, maka tidak terjadi proses belajar mengajar begitu juga sebaliknya apabila tidak ada tutornya didalam proses belajar mengajar, itu juga tidak bisa dikatakan proses belajar mengajar yang efektif, maka dari itu tutor juga harus bisa mendekatkan diri kepada peserta didiknya baik didalam proses belajar maupun di luar proses belajar, agar hubungan antara tutor dengan peserta didiknya semakin erat, sehingga timbul perasaan ingin selalu berjumpa dimana pun berada. Di luar dari kedua unsur penting tersebut, orang tua dari warga belajar tersebut harus ikut serta dalam hal proses belajar yang diikuti anaknya di Kelompok Belajar Kemuning dengan harapan anaknya dapat 
memutuskan atau bisa menyelesaikan proses belajar dengan baik dan mendapat prestasi belajar yang memuaskan. Hal ini tidak terlepas dalam hal memotivasi warga belajarnya agar selalu hadir dalam proses belajar mengajar di paket $\mathrm{C}$. Minat besar pengaruhnya terhadap belajar, karena bila bahan pelajaran yang dipelajari tidak sesuai dengan minat warga belajar, warga belajar tidak akan belajar dengan sebaik-baiknya, karena tidak ada daya tarik baginya. Slameto (2010) menyatakan bahwa minat adalah

suatu rasa lebih suka dan rasa

keterkaitan pada suatu hal

atau aktivitas, tanpa ada yang

menyuruh. Minat pada

dasarnya adalah penerimaan

akan sesuatu hubungan antara

diri sendiri dengan sesuatu

diluar diri. Semakin kuat atau

dekat hubungan tersebut,

semakin besar minat. Jika

terdapat warga belajar yang

kurang berminat terhadap

belajar, dapatlah diusahakan

agar ia mempunyai minat yang

lebih besar dengan cara

menjelaskan hal-hal yang

menarik dan berguna bagi

kehidupan serta hal-hal yang

berhubungan dengan cita-cita

serta kaitannya dengan bahan

pelajaran yang dipelajari itu.

Padahal banyak faktor yang mempengaruhi keberhasilan belajar, diantaranya adalah pendapat Oemar Hamalik (dalam skripsi 2013) mengemukakan faktor yang mempengaruhi belajar dapat dikelompokkan menjadi dua kelompok yaitu:

1. Faktor internal meliputi kemampuan dasar, minat, bakat, motivasi, sikap, penguasaan keterampilan dan kempuan dasar, aspirasi dan cita-cita dan kondisi fisiologi yang meliputi: kondisi tubuh pada umumnya, kondisi panca indera dan cacat tubuh.
2. Faktor eksternal yang berpengaruh terhadap belajar, dapatlah dikelompokkan menjadi tiga faktor yaitu faktor keluarga, faktor kelompok belajar dan faktor masyarakat.

Seperti yang dikatakan sebelumnya bahwa ada beberapa faktor yang mempengaruhinya minat belajar salah satunya faktor intern yang minat dan partisipasi warga belajar itu sendiri karena pada dasarnya minat sangat berperan penting dalam mengikuti proses belajar mengajar. Jika warga belajar tidak memiliki minat dalam belajar, maka tidak akan merespon apa yang diberikan oleh tutor dalam pembelajaran dan menunjukkan minat dalam mengikuti kegiatan pembelajaran.

Salah satu faktor yang diduga sangat berpengaruh terhadap hasil belajar adalah minat. Dalam hal ini minat merupakan landasan penting bagi seseorang untuk melakukan kegiatan dengan baik. Sebagai suatu aspek kejiwaan minat bukan saja dapat mempengaruhi tingkah laku seseorang, tetapi juga dapat mendorong orang untuk tetap melakukan dan memperoleh sesuatu. Minat dikatakan penting dalam kegiatan pembelajaran karena mempunyai pengaruh yang besar terhadap hasil belajar. Warga belajar yang memiliki minat terhadap pelajaran tertentu akan mempelajari pelajaran tersebut dengan tekun dan sungguh-sungguh. Namun sebaliknya, jika warga belajar tidak memiliki minat pada mata pelajaran tertentu maka sulit bagi warga belajar untuk dapat belajar dengan baik. Hal ini tentu saja dapat mempengaruhi hasil belajar siswa.

Minat besar pengaruhnya terhadap belajar karena minat merupakan pendorong warga belajar paket $\mathrm{C}$ dalam belajar. Semakin besar minat mereka terhadap belajar tertentu maka semakin baik pula hasil belajar yang dicapai. Sebaliknya, jika bahan pelajaran yang dipelajari tidak sesuai dengan minat siswa, siswa tidak akan belajar sebaik-baiknya karena tidak ada daya tarik baginya. Minat sangat besar 
pengaruhnya terhadap proses dan hasil belajar. Jika seseorang tidak berminat untuk mempelajari sesuatu maka tidak dapat diharapkan bahwa dia akan berhasil dengan baik dalam mempelajari hal tersebut, sebaliknya jika seseorang mempelajari sesuatu dengan penuh minat maka akan diharapkan hasilnya akan lebih baik. Minat belajar yang besar cenderung menghasilkan prestasi yang tinggi, sebaliknya minat belajar yang kurang akan menghasilkan prestasi yang rendah. Warga belajar yang memiliki minat dengan warga belajar yang tidak memiliki minat dalam belajar akan terdapat perbedaan. Perbedaan tersebut tampak jelas dengan ketekunan yang terus menerus. Warga belajar yang memiliki minat maka ia akan terus tekun ketika belajar, sedangkan warga belajar yang tidak memiliki minat walaupun ia mau belajar, tetapi ia tidak tekun dalam belajar. Begitu pula dalam proses belajar mengajar. Tinggi rendahnya minat belajar warga belajar akan memberikan pengaruh terhadap hasil belajar yang akan dicapai oleh warga belajar.

Banyak cara tutor maupun orang tua warga belajar untuk mendorong agar minat belajar warga belajarnya lebih giat lagi mengikuti proses pembelajaran paket $\mathrm{C}$ di Kelompok Belajar Kemuning yakni salah satunya memberikan tawaran hadiah kepada warga belajar atau bisa juga mengungkapkan pujian secara terangterangan kepada warga belajar. Selain memberikan tawaran hadiah atau pujian, upaya lain yang memungkinkan naiknya minat belajar adalah dengan pendekatan personal dan memberikan penjelasan akan pentingnya ilmu pengetahuan. Diharapkan dengan dilakukan berbagai cara tersebut akan mampu meningkatkan minat belajar warga belajar. Bila warga belajar memiliki keinginan untuk datang ke kelompok belajar, maka kegiatan belajar mengajar dapat dilakukan.

Namun, dilihat dari kenyataan yang sebenarnya warga belajar yang mengikuti proses belajar mengajar hanya $20 \%$ dari jumlah keseluruhan warga belajar dilihat dari tingkat kehadirannya, warga belajar masih juga terlihat belum memiliki keinginan untuk hadir dalam mengikuti proses belajar mengajar dengan tujuan meningkatkan ilmu dan pengetahuannya. Bahkan terlihat warga belajar lebih memilih menjauhkan diri dari kegiatan belajar yang sedang dijalaninya. Bekerja demi membantu perekonomian keluarga adalah salah satu alasan untuk tidak hadir dalam proses belajar mengajar, karena menurut warga belajar lebih baik bekerja mencari uang daripada mengikuti proses belajar mengajar jika dilihat dari latar belakang pekerjaan orang tua mereka sebagai nelayan penghasilan yang didapat oleh orang tua tidak mencukupi, sehingga mereka memilih ikut bekerja membantu orang tua. Bahkan menurut warga belajar rugi, bagi rumahnya yang jauh jaraknya dari kelompok belajar, karena akan mengeluarkan biaya untuk transport/perjalanan.

Selain motivasi yang rendah yang diperlihatkan warga belajar, yang mempengaruhi rendahnya minat belajar yang diperoleh warga belajar Paket $\mathrm{C}$, yaitu fasilitas belajar di kelompok belajar kemuning ini tidak dimanfaatkan dengan sebaik-baiknya. Fasilitas yang tersedia tidak dapat dimafaatkan oleh warga belajar dengan baik karena tutor juga tidak dapat memberi contoh bagaimana cara memanfaatkan fasilitas tersebut. Hal ini terjadi karena latar belakang tutor tidak memiliki kealian dan keterampilan di bidangnya. ini juga menyebabkan minat belajar warga belajar paket $\mathrm{C}$ di kelompok belajar kemuning rendah.

Dari uraian di atas maka penulis sangat tertarik untuk meneliti tentang "Faktor-faktor penyebab rendahnya minat belajar warga belajar paket $\mathrm{C}$ di kelompok belajar Kemuning Desa Asahan Mati Kecamatan Tanjungbalai Kabupaten Asahan".

\section{METODE}

Jenis penelitian yang digunakan dalam penelitian ini adalah penelitian deskriptif kuantitatif. Penelitian ini dipilih sesuai dengan masalah dan tujuan penelitian yang ingin mengetahui FaktorFaktor Penyebab Rendahnya Minat Belajar 
Warga Belajar Paket C di Kelompok Belajar Kemuning Desa Asahan Mati Kec. Tanjungbalai kabupaten Asahan. Populasi dalam penelitian ini adalah seluruh warga belajar paket $C$ yang dibina oleh SKB Asahan yang berlangsung di Kelompok Belajar Kemuning Desa Asahan Mati Kec. Tanjungbalai kabupaten Asahan yaitu 20 orang. Pengambilan sampel pada penelitian ini sesuai dengan yang diungkapkan Arikunto(2006: 134) apabila subjeknya kurang dari 100, lebih baik diambil semua sehingga penelitiannya merupakan penelitian populasi, selanjutnya jika jumlah subjeknya besar, dapat diambil antara $10 \%$ - $15 \%$ atau $20 \%-25 \%$ atau lebih. sesuai dengan pendapat di atas maka penelitian mengambil keseluruhan dari jumlah populasi (total sampling) yaitu yang berjumlah 20 orang.

Teknik pengumpulan data pada penelitian adalah angket, sejumlah pertanyaan yang digunakan untuk memperoleh informasi dari responden dalam arti laporan tentang pribadinya atau hal-hal yang ingin diketahui (Arikunto, 2002). Angket yang digunakan dalam penilaian ini adalah angket terbuka. Angket ditujukan kepada responden guna mendapatkan informasi yang diperlukan dalam penelitian. Angket berisi pertanyaan tertulis atau angket ini biasanya disebut dengan angket tertutup. Teknik analisis data, dalam penelitian ini penulis menggunakan teknik data kuantitatif, karena berbentuk deskriptif, maka digunakan tabel frekuensi dengan rumus:

$$
P=\frac{F}{N} X 100 \%
$$

Dimana :

$\mathrm{P}=$ persentase

$F=$ jumlah frekuensi

$\mathrm{N}=$ jumlah sampel/ responden (Sudijono2009).

\section{HASIL DAN PEMBAHASAN}

Sesuai dengan kuesioner/angket yang diajukan kepada warga belajar yang berjumlah 20 orang dengan 27 pernyataan mengenai faktor-faktor penyebab rendahnya minat belajar warga belajar paket $\mathrm{C}$ terbagi dalam beberapa indikator faktor Internal, yakni kesehatan jasmani maupun rohani, perhatian dan faktor Eksternal yakni lingkungan keluarga, lingkungan sekolah, dan lingkungan masyarakat pada diri warga belajar Paket $C$ di SKB Asahan. Berdasarkan indikator tersebut maka dapat dilihat hasil jawaban berikut ini:

Kesehatan Jasmani Dan Rohani sangat mempengaruhi minat belajar dapat terlihat dari jawaban warga belajar yang dominan memilih Setuju $=46 \%$ ini dikarenakan kesehatan jasmani dan rohani sangat berpengaruh dalam mengikuti kegiatan belajar karena di dalam pembelajaran harus memerlukan kondisi fisik yang sehat, jawaban Sangat Setuju= $36 \%$ yang artinya masih banyak warga belajar yang memerlukan kesehatan untuk mengikuti pembelajran atau untuk hadir ke kelompok belajar, jawaban yang menyatakan Kurang Setuju=24 \% yang artinya masih ada responden yang kurang setuju apabila mengikuti pembelajaran memerlukan kondisi yang sehat, sedangkan yang memilih Tidak Setuju $=1 \%$ yang artinya masih ada warga belajar yang tiadak mementingkan kesehatan jasmani dan rohani untuk mengikuti pembelajaran.

Melihat presentase motivasi belajar di atas, dapat disimpulkan masih banyak warga belajar yang termotivasi belajar dari dalam diri warga belajar ini terlihat masih dominannya memilih jawaban Setuju = $46 \%$ yang dikarenakan apabila untuk mengikuti pembalajaran harus dalam keadaan sehat jasmani dan rohani.

Perhatian warga belajar untuk mengikuti pembelajaran, hal ini terlihat lebih dominannya yang memilih jawaban Kurang Setuju $=33,5 \%$, ini dikarenakan rendahnya minat belajar dari dalam diri sendiri, tidak ada keinginan mengikuti kegiatan pembelajaran, kurangnya peningkatan pengetahuan di saat mengikuti proses pembelajaran, adanya merasa jenuh, kurangnya mengulangi pelajaran yang sudah diajarkan, jawaban Sangat Setutu ada $24 \%$ yang artinya masih ada 
minat belajar warga belajar mengikuti kegiatan pembelajaran dari dalam diri sendiri, masih ada perhatian warga belajar untuk mengikuti pembelajaran, sedangkan Setuju ada $30 \%$ yang menyatakan bahwa mengikuti pembelajaran perlu adanya perhatian terhadap pembelajaran hal ini sangat mempengaruhi rendahnya minat belajar warga belajar. adanya kejenuhan di saat belajar dan jawaban Tidak Setuju $11,5 \%$ yang menyatakan kurangnya minat belajar disebabkan tidak mempunyai perhatian dalam pembelajaran berlangsung.

Melihat presentase minat belajar dari warga belajar dapat disimpulkan bahwa warga belajar masih rendahnya minat belajar warga belajar, ini terlihat masih dominannya memilih jawaban kurang setuju $=33,5 \%$ ini dikarenakan tidak ada niat untuk mengikuti pembelajaran, kurangnya peningkatan pengetahuan di saat belajar, adanya rasa jenuh dalam belajar, pembelajaran yang diberikan tidak sesuai dengan kebutuhan, pembelajaran yang diberikan tidak menarik, dan pembelajaran yang di berikan terlalu sulit.

Minat belajar yang di pengaruhi lingkungan keluarga, ini terlihat masih dominannya yang memilih yang menjawab kurang setuju $=46,5 \%$, ini disebabkan pengaruh dari orang, dukungan dari orang tua, kurangnya support orang tua untuk menyuruh warga belajar agar lebih mengutamakan mengikuti proses kegiatan pembelajaran, orang tua tidak memberikan uang trasport, ada yang menjawab Tidak Setuju $=26,5 \%$ yang dikareanakan dukungan dari orang tua, hadiah yang diberikan orang tua ketika dapat nilai bagus. masih ada memilih Sangat Setuju $11,5 \%$ yang artinya masih ada minat belajar di dalam diri warga belajar disebabkan oleh dorongan/perhatian orangtua, dan perhatian orangttua terhadap pendidikan anak sedangkan masih ada yang menjawab Setuju $=15 \%$ yang dikarenakan perhatian orang tua, dan motivasi orangtua, dan perasaan ingin lebih maju.

Dari presentase minat belajar akibat tidak ada minat belajar yang timbul dari dalam diri warga belajar di atas, maka dapat disimpulkan kurangnya minat belajar dari dalam diri warga belajar karena kurangnya perhatian orangtua terhadap pendidikan warga belajar, dan warga belajar tidak berminat belajar karena tidak ada waktu untuk mengikuti pembelajaran. Ini terlihat masih dominanannya memilih jawaban kurang setuju $=46,5 \%$.

Minat belajar warga belajar dipengaruhi lingkungan sekolah, hal ini masih dominannya memilih jawaban Kurang Setuju $=31,5 \%$, ini disebabkan karena fasilitas yang ada disekolah tidak semuanya bisa digunakan, dan sumber belajar yang ada disekolah tidak sesuai kebutuhan, masih ada yang menjawab Sangat Setuju= $11,5 \%$ yang artinya masih ada yang berminat untuk belajar, yang menjawab Setuju $=23 \%$ yang artinya masih ada yang setuju dengan menggunakan semua fasilitas di sekolah, sedangkan jawaban Tidak Setuju $=16,5 \%$ artinya masih ada warga belajar menyatakan lingkungan sekolah sangat mempengaruhi minat belajar warga belajar berdasarkan jawabanjawaban responden.

Dari presentase di atas yang masih dominan memilih jawaban Kurang Setuju= $31,5 \%$ dapat disimpulkan masih ada warga belajar menyatakan lingkungan sekolah sangat mempengaruhi minat belajar warga belajar berdasarkan jawaban-jawaban responden.

Minat belajar dari lingkungan masyarakat, ini terlihat masih lebih dominannya warga belajar memilih Kurang Setuju $=30 \%$, dikarenakan kurangnya pengaruh teman untuk mendorong warga belajar untuk mengikuti kegiatan pembelajaran, kurang aktifnya warga belajar dalam kelompok belajar untuk membahas pelajaran, dan bermin dengan teman menurunkan minat belajar, tetapi masih ada yang menjawab Sangat Setuju = $25 \%$ yang artinya masih ada teman yang mengarahkan untuk mengikuti proses pembelajaran, membentuk kelompok belajar yang selalu membahas pelajaran yang menimbulkan minat belajar, ada 26,5 $\%$ yang menjawab Setuju yang artinya masih ada teman yang sering mengarahkan mengikuti proses pembelajaran, dan gunanya membentuk kelompok belajar, 
sedangkan tidak setuju $=18,5 \%$ artinya masih ada responden tidak setuju dengan pernyataaan bahwa semua anak usia tidak ada tidak sekolah.

Dari persentase di atas yang masih dominan memilih jawaban kurang setuju= $30 \%$ dapat disimpulkan pengaruh teman yang tidak mendukung peningkatan minat belajar, dan meningkatkan pengetahuan warga belajar, kurang aktifnya warga belajar menuntut ilmu di dalam kelompok belajar, dan bermain dengan teman yang tidak mendukung peningkatan minat belajar terhadap warga belajar.

Kesimpulan yang dapat diambil dari pembahasan di atas adalah faktor penyebab rendahnya minat belajar warga belajar yang paling menonjol adalah perhatian orangtua terhadap pendidikan warga belajar, dan warga belajar tidak berminat belajar karena tidak ada waktu untuk mengikuti pembelajaran.

\section{SIMPULAN}

Berdasarkan hasil penelitian yang telah dilaksanakan dapat ditarik kesimpulan sebagai berikut:

Faktor penyebab rendahnya minat belajar yaitu: (1)Faktor internal yang bersumber dari dalam diri responden itu sendiri yaitu: kurangnya motivasi dan minat belajar yang ada dari dalam diri warga belajar untuk mengikuti proses pembelajaran untuk peningkatan pengetahuan warga belajar, kurangnya perhatian warga belajar terhadap pembelajaran; (2)Faktor eksternal yang bersumber dari luar diri responden yaitu dari lingkungan keluarga seperti kurangnya perhatian orangtua terhadap pendidikan anak, dan orang tua tidak memberikan dukungan kepada warga belajar. Dari lingkungan sekolah seperti sumber yang tersedia di sekolah tidak sesuai dengan kebutuhan. Dari lingkungan Pengaruh teman yang selalu tidak mendukung warga belajar untuk mengikuti proses pembelajaran. Warga belajar belum mengerti tujuan sebenarnya menuntut ilmu.

\section{DAFTAR PUSTAKA}

Abdurrahman, Mulyono.2008. Pendidikan Bagi Anak Kesulitan Belajar. Jakarta: Rineka Cipta.

Ahmadi, Abu.1992. Psikologi Umum. Page $\mid 7$ Jakarta: Rineka Cipta.

Ahmadi Fauzi, 2004 Psikologi Umum Bandung: Pustaka Setia.

Ali, Muhammad. 1994 Donolitian Kependidikan Prosedur tegi. Bandung, Angkasa.

Armanto, Dian dan Togi,2005, Metode Penelitian, Medan, Universitas Negeri Medan.

Crow and Crow. 1989. Psikologi Pendidikan Terjemahan Kasijan. Surabaya: Bina Ilmu.

Dalyono, M 2004. Psikologi Pendidikan. Jakarta: Rineka Cipta

Depdikbud 1991. Kamus Besar Bahasa Indonesia. Jakarta Balai Pustaka.

Djamarah, Syaiful Bahri. 2000. Srtategi Belajar Mengajar. Banjarmasin: Rineka Cipta.

Dimyati, Ddk, 2005. Belajar dan Pembelajaran . Jakarta: BPFE

Hadi, Sutrisno. 2000. Analisi Rignesi. Yogyakarta: Andi Offsel.

Heri Jauhari. 2010 Panduan Penulisan Skripsi Teori Dan Aplikasi. Bandung: Pustaka Setia

Hurlock, Elizabeth,B. 2006. Psikologi Perkembangan, Jakarta. Erlangga

Kartono, Kartini. 2000. Psikologi umum . bandung : Mandur Maju Kamus Besar Bahasa Indonesia. 2005. Grasindo 


\section{Journal of Millennial Community, 1 (1), March 2019}

Suriani, Yusnadi

Loekmono, J.T.Lobby.2004. Belajar Bagaimana Belajar. Salatiga: BPK Gunung Mulia

Munawir, 2013. Faktor-faktor Penyebab Rendahnya Hasil Belajar. Skrifsi Universitas Negeri Medan.

Purwanto, Ngalim, 2014. Psikologi Pendidikan.bandung: Remaja Rosdakarya

Sagala, syaiful, Mpd 2009. Konsep dan Makna Pembelajaran. Bandung: Alfabeta

Safari . 2003. Indikator Minat Dalam Belajar. Diakses pada 27 Maret 2015.

Slameto. 2003. Belajar dan factor- faktor yang mempengaruhinya. Jakarta: rineka Cipta.
Slameto. 2010. Belajar dan Faktor-faktor yang Mempengaruhi. Jakarta : Rineka Cipta.

Sudijono, Anas 2009. Pengantar Statistik Pendidikan. Jakarta: Rajawali

Suharsimi, Arikunto, (2012), Dasar -Dasar Evaluasi Pendidikan, jakarta : Bumi Aksara.

Syah, Muhibbin 2002. Psikologi Pendidikan. Jakarta Gramedia (diakses pada 2015/ 03/20).

Syah, Muhibbin 2008. psikologi pendidikan. Bandung. Remaja Rosdakarya Offsel.

Walgito, Bimo, 2010. Psikologi Social. Jakarta: Rineka Cipta 